\title{
Kinetics and thermodynamics study of lead adsorption on to activated carbons from coconut and seed hull of the palm tree
}

\author{
S. Gueu, * B. Yao, K. Adouby, G. Ado \\ Institut National Polytechnique Félix Houphouët-Boigny,Département Génie Chimique et Agroalimentaire,Laboratoire \\ des Procédés Industriels, de Synthèse et de l'Environnement,Yamoussoukro, Côte d'Ivoire.
}

Received 9 November 2006; revised 25 November 2006; accepted 7 December 2006; available online 1 January 2007

\begin{abstract}
The kinetic and thermodynamic of the bath sorption of lead $(\mathrm{Pb})$ on to activated carbon from Coconut (CA) and Seed hull of the Palm tree (GA) have been investigated. The effects of initial $\mathrm{Pb}$ concentration, contact time and temperature were examined. The results showed that the adsorption capacities of the activated carbons increased with the initial lead concentration. The process sorption followed a pseudo first order kinetics and parameters such as $\mathrm{Ea}$ and $\mathrm{k}_{0}$ were determined. It could be best fitted by the Langmuir and Freundlich isotherms. From the first, the equilibrium sorption capacities of lead ion were determined and found to be respectively 4.38 and $3.77 \mathrm{mg} /$ $\mathrm{g}$ for $\mathrm{CA}$ and GA at $60{ }^{\circ} \mathrm{C}$. The thermodynamic parameters such as $\Delta \mathrm{H}, \Delta \mathrm{S}$ and $\Delta \mathrm{G}$ were computed from the experimental data. These values show that the adsorption is endothermic and non spontaneous. Moreover, the relative weak values of $\Delta \mathrm{H}(\sim 5 \mathrm{kcal} / \mathrm{mol})$ confirm a physical adsorption. The maximum adsorptions were obtained at $60{ }^{\circ} \mathrm{C}, \mathrm{pH}$ 4 and with a $\mathrm{Pb}$ initial concentration of $100 \mathrm{mg} / \mathrm{L}$.
\end{abstract}

Key words: Heavy metals, activated carbon, langmuir and freundlich isotherms, adsorption, kinetic, thermodynamic

\section{INTRODUCTION}

The development of industries such as coating, electric battery manufacturing, paint, lead smelting, internal combustion engines, generates large quantity of wastewaters containing large quantity of lead. This metal is potentially toxic as reported by Goyer and Chisolon, (1972) and Assenato, et al., (1986). So its removal from industrial wastewaters remains an important challenge. For instance, in similar works, Carrasqueros, et al., (2006) showed that a vermicompost allows to uptake $123.5 \mu \mathrm{g} / \mathrm{g}$ of lead at $50^{\circ} \mathrm{C}$ and Sekar et al., (2004) used an activated carbon from coconut shell to adsorb $26.5 \mathrm{mg} / \mathrm{g}$ of lead from aqueous solution at $65{ }^{\circ} \mathrm{C}$. We recently showed that activated carbon prepared in a simple manner from Coconut shell and Seed hull of the Palm tree could present good property in heavy metals uptake (Gueu, et al., 2006). This study that is the logical continuation of the first one approaches the kinetic, equilibrium isotherm and thermodynamic aspects. The isotherms of adsorption were established and the results modelled by the Langmuir and Freundlich isotherm.

\footnotetext{
*Corresponding author, Email: beyao@yahoo.fr

Tel.: +2250780 0519; Fax: +225 30640406
}

\section{MATERIALS AND METHODS}

Activated carbons preparation

The dry coconut and the Seed hull of the Palm tree were initially scraped with a knife to remove all fibres present at surface, and then crushed using a crushing mill Retsch Germany of the type BB 100 Rosrfrei. The resulting product was recovered, washed several times with distilled water to eliminate the water soluble impurities, then oven dried at $105^{\circ} \mathrm{C} .250 \mathrm{~g}$ of the small pieces of this last, were mixed with $35 \mathrm{~mL}$ of concentred orthophosphoric acid. The mixture was carbonized at 400 ${ }^{\circ} \mathrm{C}$ during $16 \mathrm{~h}$. The sample was then withdrawn from the furnace and cooled in a desiccator. After cooling, the sample was rinsed several times with distilled water until obtaining a flushing water whose $\mathrm{pH}$ range between 6 and 7 . The wet sample was dried at $105^{\circ} \mathrm{C}$ during $24 \mathrm{~h}$. It was then crushed and filtered. Only the particles of size ranging between $0.5 \mathrm{~mm}$ and $0.2 \mathrm{~mm}$ are recovered. CA represents the sample obtained from coconut and GA, the other one obtained from seed hull of cabbage tree.

General procedure for kinetic and equilibrium studies A $50 \mathrm{~mL}$ volume lead nitrate salt aqueous solution with concentration ranging from 100 to $500 \mathrm{mg} / \mathrm{L}$ was 
placed in four conical flasks containing $6 \mathrm{~g}$ of activated carbon (GA or CA). The $\mathrm{pH}$ was adjusted to 4 and the conical flasks were shaken in a shaking water bath at temperature ranging from 30 to $60^{\circ} \mathrm{C}$ for a determined time. The carbons were separated by filtration and the filtrates were analysed for the remaining lead concentration by atomic adsorption Spectrophotometry (Varian AA20).

\section{RESULTS}

Sorption isotherms studies

In order to determine isotherm model that described more accurately the experimental data, the Langmuir and Freundlich ones were analysed. The model developed by Langmuir (1916) is represented by the following linearised equation:

$$
\frac{C_{e}}{q_{e}}=\frac{1}{q_{m} b}+\frac{C_{e}}{q_{m}}
$$

where $\mathrm{q}_{\mathrm{e}}$ is the equilibrium quantity sorbed (en $\mathrm{mg} / \mathrm{g}$ ), $\mathrm{C}_{\mathrm{e}}$ the equilibrium concentration $(\mathrm{mg} / \mathrm{L}), \mathrm{q}_{\mathrm{m}}$ the maximum saturation capacity of the activated carbon $(\mathrm{mg} / \mathrm{g})$ and $\mathrm{b}$ the sorption equilibrium constant $(\mathrm{L} / \mathrm{mg})$. The Freundlich isotherm (1906) is expressed by the following linearised equation:

$$
\log _{e}=\log _{F}+\frac{1}{n} \log C_{e}
$$

where $\mathrm{K}_{\mathrm{F}}$ and $\mathrm{n}$ are empirical constants.

According to the experimental data, the plot of $\frac{C_{e}}{q_{e}}$ as a function of $C_{e}$ and $\log \mathrm{q}_{e}$ as a function of $\log \mathrm{C}_{\mathrm{e}}$ at different temperature (Figs. 1, 2, 3 and 4) illustrates the applicability of the two models postulated.

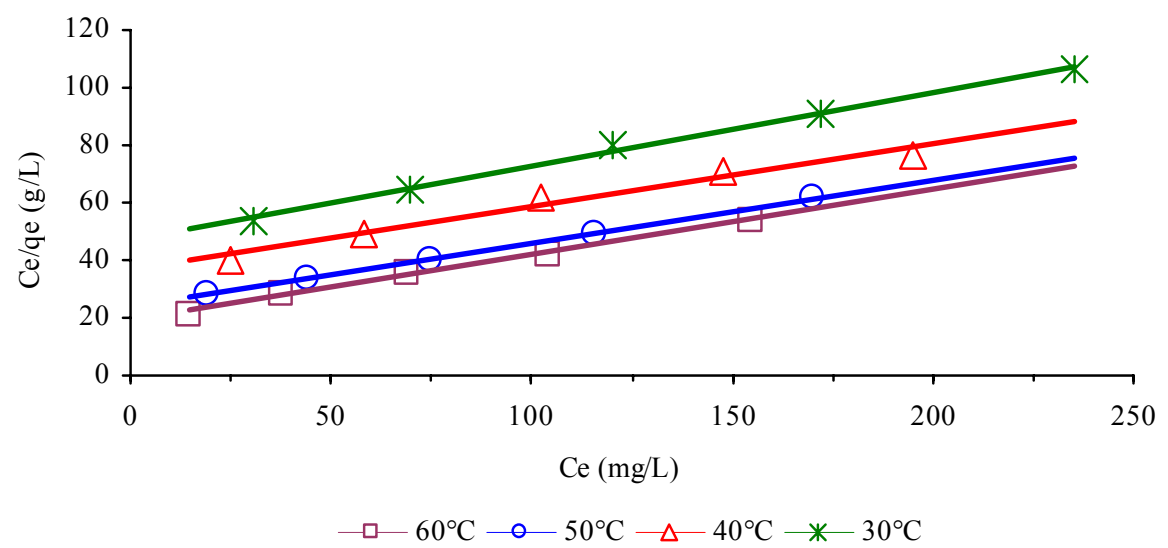

Initial lead concentration $=100 \mathrm{mg} / \mathrm{L}, \mathrm{pH} 4$ and adsorbent dose $=6 \mathrm{~g}$

Fig. 1: Langmuir isotherm for the lead sorption using $\mathrm{CA}$ at different temperatures

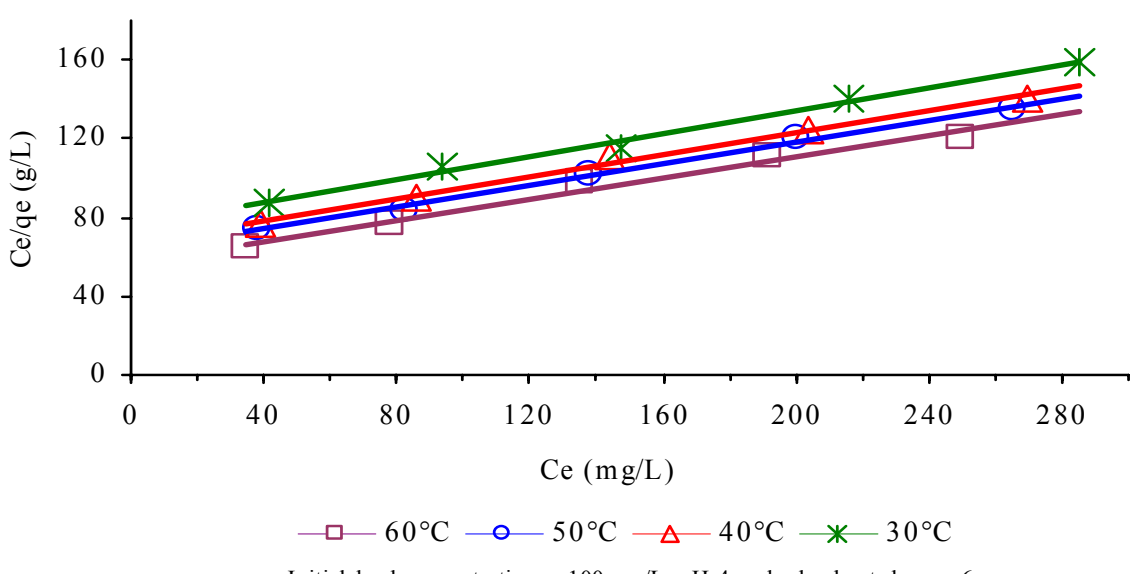

Fig. 2: Langmuir isotherm for the lead sorption using GA at different temperatures 


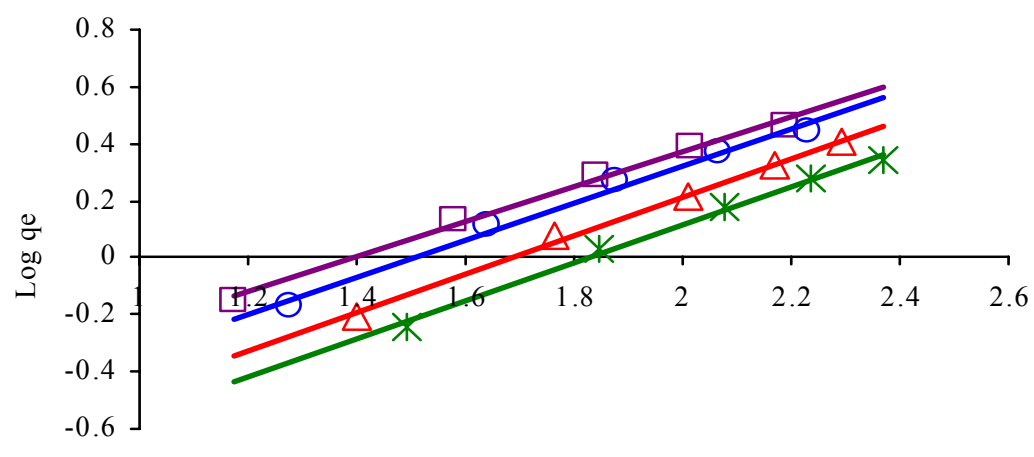

$\log \mathrm{Ce}$

$\square 60^{\circ} \mathrm{C}-50^{\circ} \mathrm{C} \triangle 40^{\circ} \mathrm{C} \longrightarrow 30^{\circ} \mathrm{C}$

Initial lead concentration $=100 \mathrm{mg} / \mathrm{L}, \mathrm{pH} 4$ and adsorbent dose $=6 \mathrm{~g}$

Fig. 3: Freundlich isotherm for the lead sorption using $\mathrm{CA}$ at different temperatures

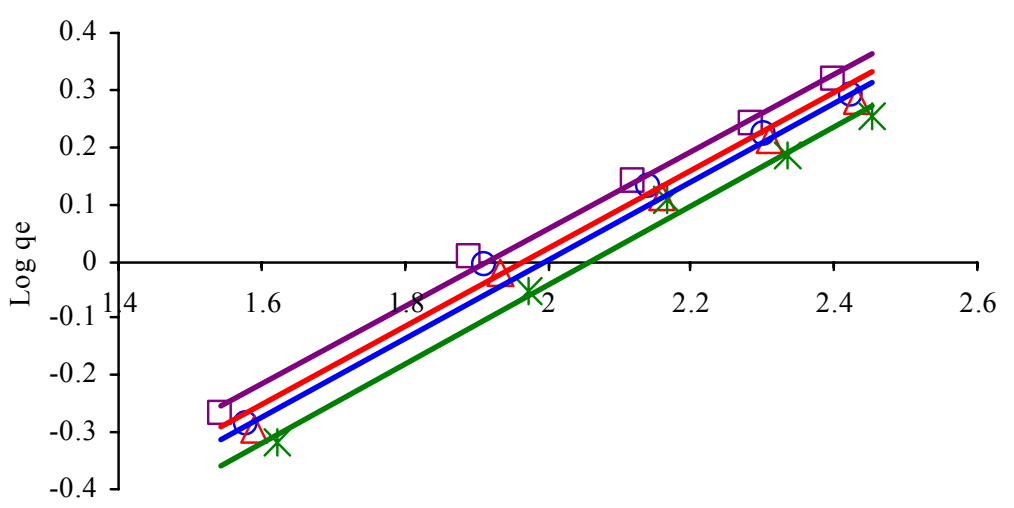

$\log \mathrm{Ce}$

$\longrightarrow 60^{\circ} \mathrm{C} \longrightarrow 50^{\circ} \mathrm{C} \triangle 40^{\circ} \mathrm{C} \rightarrow 30^{\circ} \mathrm{C}$

Initial lead concentration $=100 \mathrm{mg} / \mathrm{L}, \mathrm{pH} 4$ and adsorbent dose $=6 \mathrm{~g}$

Fig. 4: Freundlich isotherm for the lead sorption using GA at different temperatures

Table 1: Models coefficient, Chi-square and determination coefficients for two isotherms using CA

\begin{tabular}{llllccccc}
\hline & Langmuir & \multicolumn{7}{c}{ Freundlich } \\
\cline { 2 - 9 } $\mathrm{T}\left({ }^{\circ} \mathrm{C}\right)$ & $\mathrm{q}_{\mathrm{m}}(\mathrm{mg} / \mathrm{g})$ & $\begin{array}{l}10^{3} \mathrm{~b} \\
(\mathrm{~L} / \mathrm{mg})\end{array}$ & $10^{3} \chi^{2}$ & $\mathrm{R}^{2}$ & $\mathrm{~K}_{\mathrm{F}}$ & $1 / \mathrm{n}$ & $10^{3} \chi^{2}$ & $\mathrm{R}^{2}$ \\
\hline 30 & 3.91 & 5.45 & 01.65 & 0,9959 & 0,0605 & 0,6669 & 08.83 & 0,9942 \\
40 & 4.56 & 6.00 & 09.14 & 0,9765 & 0,0731 & 0,6742 & 03.33 & 0,9976 \\
50 & 4.52 & 9.31 & 00.62 & 0,9991 & 0,1059 & 0,6495 & 32.69 & 0,9861 \\
60 & 4.38 & 12.1 & 05.23 & 0,9946 & 0,1417 & 0,6088 & 17.67 & 0,9931 \\
\hline
\end{tabular}

Table 2: Models coefficient, Chi-square and determination coefficients for two isotherms using CA

\begin{tabular}{llllclclc}
\hline & Langmuir & \multicolumn{7}{c}{ Freundlich } \\
\cline { 2 - 8 } $\mathrm{T}\left({ }^{\circ} \mathrm{C}\right)$ & $\mathrm{q}_{\mathrm{m}}(\mathrm{mg} / \mathrm{g})$ & $\begin{array}{l}10^{3} \mathrm{~b} \\
(\mathrm{~L} / \mathrm{mg})\end{array}$ & $10^{3} \chi^{2}$ & $\mathrm{R}^{2}$ & $10^{3} \mathrm{~K}_{\mathrm{F}}$ & $1 / \mathrm{n}$ & $10^{3} \chi^{2}$ & $\mathrm{R}^{2}$ \\
\hline 30 & 3.40 & 3.90 & 11.64 & 0.9917 & 37.68 & 0.6912 & 08,34 & 0.9922 \\
40 & 3.58 & 4.16 & 01.77 & 0.9936 & 42.92 & 0.6839 & 04,94 & 0.9957 \\
50 & 3.57 & 4.48 & 01.39 & 0.9962 & 45.75 & 0.6804 & 11,22 & 0.9909 \\
60 & 3.77 & 4.61 & 07,35 & 0.9763 & 51.04 & 0.6731 & 04,65 & 0.9957 \\
\hline
\end{tabular}


From these graphs, the corresponding parameters of the two models, the linear coefficient of determination $\left(\mathrm{R}^{2}\right)$ and Chi-square $\left(\chi^{2}\right)$ are determined (Tables 1 and 2 ), and allows conclusion to be drawn on the accuracy of each of them to explained the experimental data. A model will be find to be suitable if $\mathrm{R}^{2}$ is equal to one and $\chi^{2}$ the smaller as possible. On this basis the Langmuir isotherm can be considered as the most suitable model for sorption on CA. However, it is difficult to conclude in the case of GA. So the two isotherms should be considered as suitable to explain the experimental data. Moreover, the values of $\mathrm{q}_{\mathrm{m}}$, and $\mathrm{b}$ increase for an increase in the solution temperature. This is an indication of the improvement of adsorption with the increase in the temperature. That is confirmed by the increase with temperature of constant $\mathrm{K}_{\mathrm{F}}$ obtained from Freundlich model (Sreedhar, et al., 1999). At the whole, CA gives constants higher and can be regarded as better than GA.

\section{Kinetic studies}

Assuming a pseudo-first-order kinetic, the Lagergren equation was used for the studied (Lagergren, 1898). This equation can be written as follows:

$$
\log \left(q_{e}-q_{t}\right)=\log \left(q_{e}-\frac{K_{a d}}{2,303} t\right)
$$

Where $\mathrm{q}_{\mathrm{t}}$ and $\mathrm{q}_{\mathrm{e}}$ are respectively metal ion sorbed per unit weight of carbon at any time and at equilibrium. The plot of $\log$ (qe-qt) as a function of the time and for a serie of initial concentration of lead ranging from 100 to $400 \mathrm{mg} / \mathrm{L}$ is given by fig. 5 and 6 . The linear relationships obtained $\left(\mathrm{R}^{2} \geq 0.97\right)$ confirm the first order kinetic. Moreover, the kinetic constants vary in a random way and independently of the initial concentration, confirming the first order reaction. An examination of the temperature effect, (Table 3 and Fig.6) shows that the values of constant rate increase from 0.0345 to $0.0435 \mathrm{~min}^{-1}$ for CA and 0.0339 to $0.0396 \mathrm{~min}^{-1}$ for GA. Theses results confirm the better sorption capacity of CA.

A linear relationship between the pseudo-rate constant and temperature is obtained and given in the Arrhenius form as:

$$
\begin{array}{ll}
k_{C A}=0.4015 \exp \left(\frac{-6.1648}{8.314 T}\right) & R^{2}=0.973 \\
k_{G A}=0.196 \exp \left(\frac{-4.4}{8.314 T}\right) & R^{2}=0.976
\end{array}
$$

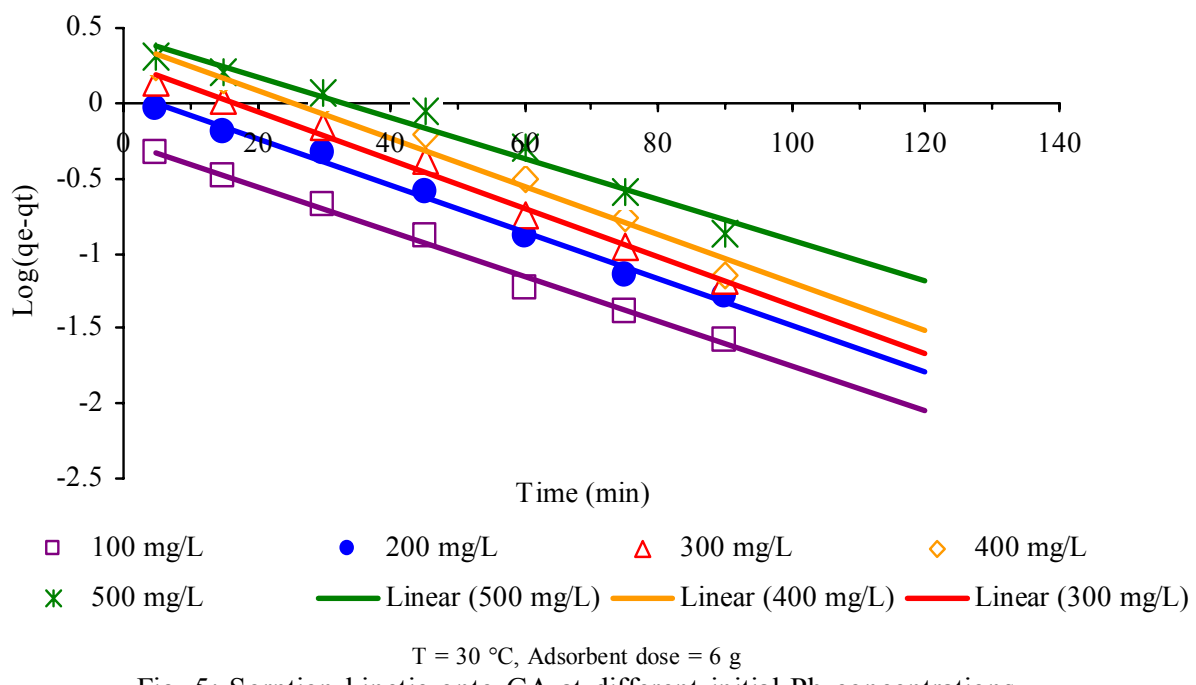

Fig. 5: Sorption kinetic onto $\mathrm{GA}$ at different initial $\mathrm{Pb}$ concentrations

Table 3: Adsorption first-order constants rate obtained for various temperatures

\begin{tabular}{llclc}
\hline \multirow{2}{*}{$\mathrm{T}\left({ }^{\circ} \mathrm{C}\right)$} & \multicolumn{3}{l}{$\mathrm{GA}$} & \\
\cline { 2 - 5 } & $\mathrm{k}_{\mathrm{ad}} / \min$ & $\mathrm{R}^{2}$ & $\mathrm{~K}_{\mathrm{ad}} / \min$ & $\mathrm{R}^{2}$ \\
\hline 30 & $3.4510^{-2}$ & 0.9936 & $3.3910^{-2}$ & 0.9654 \\
40 & $3.8510^{-2}$ & 0.9927 & $3.6410^{-2}$ & 0.9883 \\
50 & $4.0010^{-2}$ & 0.9984 & $308510^{-2}$ & 0.9617 \\
60 & $4.3510^{-2}$ & 0.9909 & $3.9610^{-2}$ & 0.9680 \\
\hline
\end{tabular}


Int. J. Environ. Sci. Tech., 4 (1): 11-17, 2007

Table 4: thermodynamic parameters

\begin{tabular}{llll}
\hline CA & & $\mathrm{GA}$ & $\Delta \mathrm{G}^{\circ} / \mathrm{kJ} / \mathrm{moL}$ \\
\hline Temperature $\left({ }^{\circ} \mathrm{C}\right)$ & $\Delta \mathrm{G}^{\circ}(\mathrm{kJ} / \mathrm{moL})$ & Temperature $\left({ }^{\circ} \mathrm{C}\right)$ & 13.98 \\
30 & 13.32 & 30 & 14.27 \\
40 & 12.98 & 40 & 14.57 \\
50 & 12.89 & 50 & 14.88 \\
60 & 12.30 & 60 & $\Delta \mathrm{S}^{\circ}(\mathrm{J} / \mathrm{moL} . \mathrm{K})$ \\
$\Delta \mathrm{H}^{\circ}(\mathrm{kJ} / \mathrm{moL})$ & $\Delta \mathrm{S}^{\circ}(\mathrm{J} / \mathrm{moL} . \mathrm{K})$ & $\Delta \mathrm{H}^{\circ}(\mathrm{kJ} / \mathrm{moL})$ & -30.17 \\
23.65 & 34.08 & 4.83 & \\
\hline
\end{tabular}

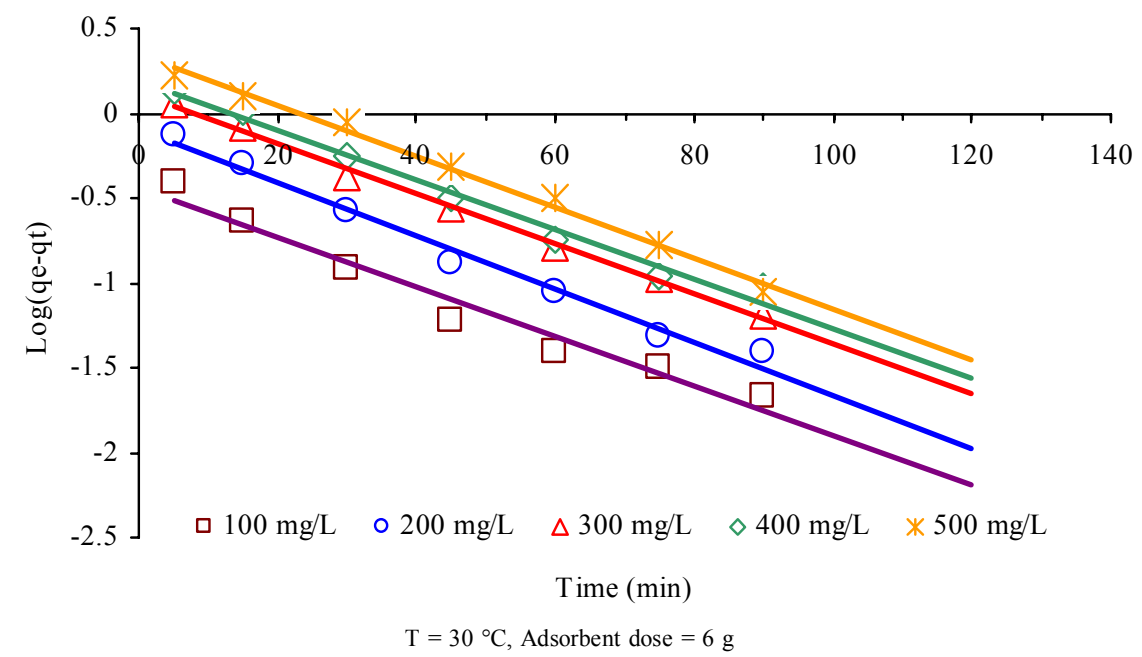

Fig. 6: Sorption kinetic onto $\mathrm{GA}$ at different initial $\mathrm{Pb}$ concentrations

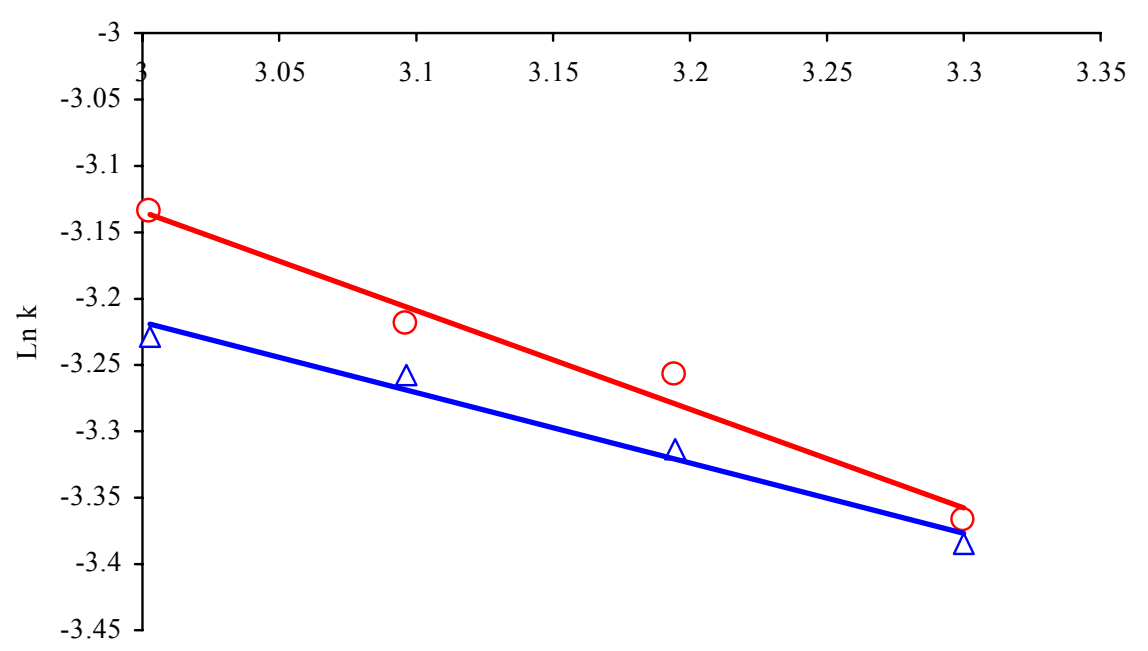

$1000 / \mathrm{T}(1 / \mathrm{K})$

○ CA $\triangle \mathrm{GA}$

Fig. 7: Relationship between adsorption first order constant rate and temperature 


\section{Thermodynamic studies}

In order to determine the thermodynamic feasibility an the thermal effects of the sorption, the Gibbs free energy $\left(\Delta \mathrm{G}^{\circ}\right)$ the entropy $\Delta \mathrm{S}^{\circ}$ and the enthalpy $\left(\Delta \mathrm{H}^{\circ}\right)$ where calculated. The $\Delta \mathrm{G}^{\circ}$ is the fundamental criterion to determine if a process occurs spontaneously. For a given temperature, a phenomenon is considered to be spontaneous if the $\Delta \mathrm{G}^{\circ}$ has a negative value. Moreover, if $\Delta \mathrm{H}^{\circ}$ is positive, the process is endothermic and if it is negative, the process is exothermic. For the determination of $\Delta \mathrm{H}^{\circ}$ and $\Delta \mathrm{S}^{\circ}$, the relationship between sorption equilibrium constant $b$ and Gibbs free energy was considered at any temperature:

$$
L n b=\frac{\Delta S^{\circ}}{R}-\frac{\Delta H^{\circ}}{R T}=-\frac{\Delta G^{\circ}}{R T}
$$

The plot of Lnb as a function of 1/T (Fig. 8) should give a linear relationship with slope of $\Delta \mathrm{H}^{\circ} / \mathrm{R}$ and an intercept of $\Delta \mathrm{S}^{\circ} / \mathrm{R}$. Then $\Delta \mathrm{G}^{\circ}$ is obtained at any temperature from the following equation:

$\Delta G^{\circ}=\Delta H^{\circ}-T \Delta S^{\circ}$

The plot of Lnb as a function of 1/T (Fig. 8) gives effectively a linear relationship with determination coefficients of 0.9436 and 0.9789 respectively for CA and GA. It results from it, the thermodynamic parameters indicated in Table 4. The positive and weak value of $\Delta \mathrm{G}^{\circ}$ indicates that the process is feasible but non spontaneous. On the other hand, the value of $\Delta \mathrm{H}^{\circ}$ is positive, indicating that the sorption is endothermic.

\section{DISCUSSION AND CONCLUSION}

The study showed the ability of CA and GA to sorbed lead from aqueous solution. The adsorption was found to be initial concentration and temperature dependant. The Chi-square test indicated that sorption data can be adequately modelled by Langmuir and Freundlich isotherm. The kinetic studies allowed the validation of a first order mechanism. The low values of the activated energies ( 6.16 for CA and $4.4 \mathrm{~kJ} / \mathrm{mol}$ for GA) indicate that the adsorption presents a low potential energy barrier.

These values are more consistent of a physical sorption process. Many authors arrived at such results. Among them, Krishnan, et al., 2003 and Ho, et al., 2005 who obtained Ea equal respectively to 18.8 and 13.5 $\mathrm{kJ} / \mathrm{moL}$. The low values of enthalpy validate well the assumption of a physical adsorption. In the case of $\mathrm{CA}$, the positive value of $\Delta \mathrm{S}^{\circ}$ indicates the increasing randomness of the system (Sreedhar, et al., 1999), while the randomness decreases in the case of GA for which $\Delta \mathrm{S}^{\circ}$ has a negative value.

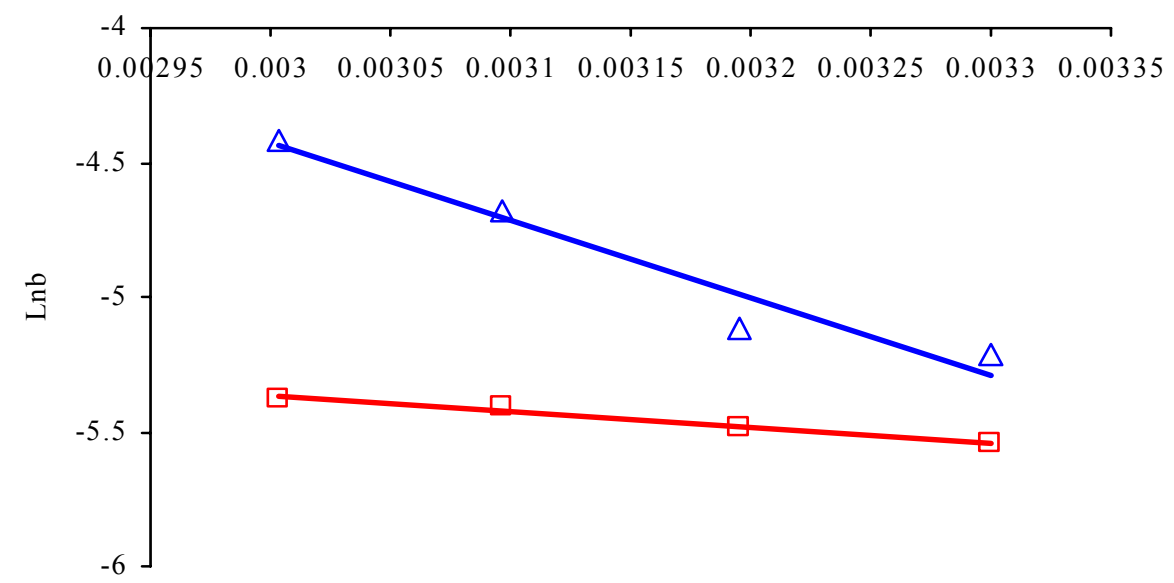

$1 / \mathrm{T}(1 / \mathrm{K})$

$\triangle \mathrm{CA} \square \mathrm{GA}$

Fig. 8: Relationship between Langmuir sorption equilibrium constant and temperature for CA and GA 


\section{REFERENCES}

Assenato, G., Paci, C., Baser, M.C., Molinini, R., Candela, R. M., Altamura B.M., Giorgino, R., (1986). Sperm count suppression without endocrine dysfunction in lead-exposed men. Arch. Environ. Health, 4, 387-390.

Carrasquero Duran, A., Flores, I., Perozo, C and Pernalete, S., (2006). Immobilization of lead by vermicompost an its effect on white bean (Vigna Sinenis var. Apure) uptake. Int. J. Environ. Sci. Tech., 3 (3), 203-212.

Freundlich, H.M.F., (1906). Uber die adsorption in losungen. Z. Phys. Chem., 57 (A), 385-470.

Gueu, S., Yao, B, Adouby, K., Ado, G., (2006). Heavy metals removal in aqueous solution by activated carbons prepared from coconut shell and seed shell of the palm tree. J. Appl. Sci., 6 (13), 2789-2793.

Goyer R.A., Chisolon, I.J., (1972). Lead in metallic contaminations and human health. Lee, D.H.K. (Ed). Academic Press, New York, P.57.

Ho, Y.S., Ofomaja, A.E., (2005). Kinetics and thermodynamics of lead ion sorption on palm kermel fibre from aqueous solution. Proc. Biochem., 40, 3455-3461.
Krishnan, K.A., Anirudhan T.S., (2003). Removal of cadmium (II) from solutions by steam-activated sulphurised carbon prepared from sugar-cane bagasse pith: Kinetics and equilibrium studies, Water SA., 29 (2), 147-156.

Langmuir, I., (1916). The constitution and fundamental properties of solids and liquids. J. Am. Chem. Soc., 38 (11), 2221-2295.

Lagergren, S., (1898). Zur theorie der sogenannten adsorption gelöster stoffe, Kungliga Svenska Vetenskapsakademiens. Handlingar, 24 (4), 1-39.

Serkar, M., Sakthi, V. and Rengaraj, S., (2004). Kinetics and equilibrium adsorption study of lead (II) onto activated carbon prepared from coconut shell. J. Coll. Inter. Sci., 279 (2), 307-307.

Sreedhar, M.K., Madhukumar, A., Anirudhan, T.S., (1999), Evaluation of an adsorbent prepared by treating coconut husk with polysulphide for the removal of mercury from wastewater. Indian J. Eng. Mater. Sci., 6 (5), 279-285.

\section{AUTHOR (S) BIOSKETCHES}

Gueu, S., M.Sc. student in the industrial process, Synthesis and Environmental Laboratory, Polytechnic National Institute Houphouët-Boigny of Yamoussoukro, Ivory Coast. Email: gueu05@yahoo.fr

Yao, B., M.Sc., Ph.D. in industrial science, professor in the Polytechnic National Institute Houphouët-Boigny of Yamoussoukro, Ivory Coast, Chief of the Industrial Process, Synthesis and Environmental Laboratory. Email: beyao@yahoo.fr

Adouby, K., M.Sc., Ph.D. in materials science, associated professor in the Polytechnic National Institute Houphouët-Boigny of Yamoussoukro, Ivory Coast. Researcher in the industrial process, Synthesis and Environmental Laboratory. Email: kadouby@yahoo.fr

Ado, G., M.Sc., Ph.D. in materials science, professor, Head Manager of Polytechnic National Institute Houphouët-Boigny of Yamoussoukro, Ivory Coast. Researcher in the industrial process, Synthesis and Environmental Laboratory. Email : adogossan@yahoo.fr

\section{This article should be referenced as follows:}

Gueu, S., Yao, B., Adouby, K., Ado, G., (2007). Kinetics and thermodynamics study of lead adsorption onto activated carbons from coconut and seed hull of the palm tree. Int. J. Environ. Sci. Tech., 4 (1),11-17. 